\title{
Development of an Auditing Framework by Integrating ISO 9001 Principles within Auditing
}

\author{
Omran Ahmad Abuazza, University of Portsmouth
}

Ashraf Labib, University of Portsmouth

Barbara Savage, University of Portsmouth

\section{Abstract}

Purpose

To develop an auditing framework which would assist the organizations that experience difficulties with the current ISO 9001 quality audits to achieve their planned objectives with regard to their auditing of conformance, performance, risk management and improvement collectively.

Methodology

A literature review was conducted to develop a conceptual audit framework (CAF). Subsequently, a preliminary audit framework (PAF) was developed. It includes the questions that are based on the CAF and connected with the complaints of the concerned organization. This PAF was thoroughly tested and validated by performing eleven internal audits, two management reviews and three workshops.

Findings

Applying this PAF indicated that in order to help organizations to audit their performance, risk management and improvement collectively, they need to; 1) change their audit approach from ISO elements to ISO Principles, 2) integrate the tools that are related to ISO 9001 Principles within the audit's phases, 3) perform pre-audits in the form of self-auditing, 4) induce auditors to learn all tools to determine the ideal tools for particular situation, 5) audit each department in combination with its internal customer, 6) involve their auditors in problem solving, 7) Perform management review prior to closing the audit, and 8) analyze the results of audits with their causes by using one of the appropriate qualitative methods, such as analysis by themes.

Finally, an auditing framework was developed to meet these needs. It includes the PAF's questions that led to the discovery of chronic and systematic audit findings. It enhances any ISO 9001 Quality Auditing Questionnaires Checklist.

Originality/value

Enhancing the role of auditors to include risk identification, problem solving and data analysis by development of an Auditing Framework that is based on ISO 9001 Principles rather than clauses.

Key Words: Integration, management tools, ISO 9001 principles, auditing framework. 
Type: $\quad$ Research Paper

\section{Introduction, Problem Identification and Rationale}

The Great Man-made River Authority [GMRA] in Libya manages and operates Pre-stressed Concrete Cylinder Pipelines [PCCP] as a part of the Great Man-made River Project [GMRP], which has been in operation since 1990. This pipeline carries water from Sahara's Southern aquifers to the northern urban coastal area and provides $70 \%$ of the Libyan population with water. The pipeline consists of approximately 4,000 km of PCCP sized from 1.6 to 4.0 metre diameter and approximately 980 wells producing approximately 5.0 million cubic meters of water per day. The pipeline of this project was designed to carry water for at least 50 years without problems, but actually it has experienced many technical failures in 1999, 2000, 2002 and 2003, 2012 and 2013 (Abuazza, Elaish and Nawa, 2007). According to the investigation that was carried out by GMRA in 2014, it was concluded that none of these failures were predicted by any of the internal or external audits conducted during that period.

With reference to GMRA, (2014, P. 5), a complaint was raised by GMRA top management related to its internal audits results, identifying that.

"a The internal audits were not effective for determining the new threats, risks and opportunities resulting from the last political change in Libya.

$b \quad$ The internal audits have failed to identify many warning indicators with regard to the technical failures that were taken place during the period of 2000-2013. Though, specialized technicians have been involved in these audits.

c The contents of the current audit reports do not communicate information or data that are critical to the integrity of infrastructure.

$d \quad$ The current internal audit does not bring value, in terms of auditing of performance, risk management and improvement.

$e \quad$ The current internal auditors have failed to make the auditees supporter instead of disbelievers of the audit process. Though, these internal auditors are certified and have the technical knowledge that is related to the audited process.

$f \quad$ GMRA is registered to ISO 9001, ISO 14001 and OHSAS 18001 Standards, but no added value in terms of performance, risk management and improvement was provided.

$g \quad$ Auditors perform audits by sampling, but the number of samples audited are always limited, considering the great size of the project".

Due to these complaints, and in response to most of these limitations, a literature review was undertaken to determine whether these limitations are applicable to the other organizations that implement the ISO 9001 Standard in their quality audit and to determine the other limitations and enhancements that are generally associated with this kind of audit. 


\subsection{Limitations of ISO 9001 quality audits}

These kinds of GMRA's complaints were found applicable with many other organizations that implement ISO 9001 quality audit as reported in the following literature (Table I):

\begin{tabular}{|c|c|}
\hline \multicolumn{2}{|r|}{ Table 1 of 12} \\
\hline $\begin{array}{l}\text { GMRA's } \\
\text { complaint }\end{array}$ & What have the associated authors reported? \\
\hline Complaint a & $\begin{array}{l}\text { Karapetrovic and Willborn (2000), Hoyle and Thompson (2004) and Russell (2006) } \\
\text { advocated changing the current approach of audits from conformance to performance in order to } \\
\text { better assess the performance of the quality management system. }\end{array}$ \\
\hline Complaint b & $\begin{array}{l}\text { Broadleaf (2014) reported that the audit may not be effective to audit the risk management for } \\
\text { organizations which have no documented risk management framework. }\end{array}$ \\
\hline Complaint c & $\begin{array}{l}\text { Failure to prevent recurrence of problems (Russell, 2004). Wells (2010) argues that audit } \\
\text { findings do not generate excitement and urgency in top management because they are typically } \\
\text { expressed as non conformances with standards and procedures. He goes on to recommend those } \\
\text { audit findings should be expressed in terms of money which is the metric that top management } \\
\text { understands and is interested in. } \\
\text { Use of immaterial audit evidence as a base for decision making (Russell 2013). }\end{array}$ \\
\hline $\begin{array}{l}\text { Complaints d } \\
\text { and a }\end{array}$ & $\begin{array}{l}\text { Hoyle and Thompson (2004) and Russell (2006) reported that some auditors fail to identify } \\
\text { audit findings and their causes correctly and accurately. } \\
\text { Russell (2013) addressed that some the quality auditors focus on looking at compliance with ISO } \\
9001 \text { clauses and he advocated changing the current approach of audits from conformance to } \\
\text { performance. }\end{array}$ \\
\hline $\begin{array}{l}\text { Complaints c } \\
\text { and e }\end{array}$ & $\begin{array}{l}\text { He (2016, P.29) suggested that in some way, "at the beginning of an audit, an auditor is blind to } \\
\text { a certain degree or in a certain area. People who are not blind still make mistakes similar to those } \\
\text { in the blind men's tale, such as taking a one-sided or isolated view of things, or drawing a } \\
\text { conclusion based on insufficient information". } \\
\text { Imperfect recognition of the customer of the audited process (Malsbury, 1999). }\end{array}$ \\
\hline Complaint $\mathrm{f}$ & $\begin{array}{l}\text { Ramly, Ramly and Yusuf (2008, P. 26) asserted that "many organizations are ISO certified, but } \\
\text { audit has been regarded traditionally as added cost activities and fail to improve the organization } \\
\text { performance". They argue that "audit should focus toward improving the process performance, } \\
\text { product quality, reduction of waste, improve service and cost reduction". }\end{array}$ \\
\hline Complaint g & $\begin{array}{l}\text { Inadequate and improper use of sampling methods when collecting audit evidence (Karapetrovic } \\
\text { and Willborn 2000). Kausek (2008b, P. 3) shows that "Auditors should examine each question } \\
\text { on their checklists and ask themselves, 'How will we verify the auditee's response? Do we know } \\
\text { what to ask for and how we will choose the samples?' If the answer is not evident, the auditor } \\
\text { should develop a verification strategy and add it to the checklist". Therefore, the method of } \\
\text { sampling should be determined and verified. }\end{array}$ \\
\hline
\end{tabular}

Table I: Similarities between GMRA's complaints and the audit's limitations reported in the literature 
By reviewing GMRA's complaints (a, b, c, d and e) of Table I against the new version of ISO 9001:2015 Standard, it is perceived that GMRA's complaint number a and part of complaint number b have already been covered by this standard. However, the other complaints number $\mathrm{c}, \mathrm{d}$ and e are not seemed to be sufficiently covered by this new standard. They are more likely to be related to the auditing techniques rather than the requirements of this standard.

The authors of this paper believe that the audit's difficulties of Russell (2013), He (2016) and Malsbury (1999) of Table I have not been adequately covered by the new version of ISO 9001:2015 standard, because they are also related to the audit techniques rather than the standard.

This Literature Review also resulted in determination of some audit program strategies which have been recommended by some authors to overcome some of these audit limitations, and that are applicable to these customer complaints.

\subsection{Overcoming the limitations of ISO 9001 Quality Audit}

\subsubsection{Induce Auditors to Attain the Skills Needed for Assertion, Materiality and Sampling}

Due to the possibility of not auditing the most important things of the audited process, it is important for auditor to ensure auditing of real representations by having the skills needed for sampling, assertion and materiality (PECB 2016). Kausek (2008) presented 10 rules that if practiced as he stated, will significantly improve the effectiveness of the audit. One of those rules is: "Never let the auditee pick the samples". The ABP Consultant (2016) state that the determination of sample size and selection should be based on: complexity, volume, risk, past problems and audit time span. But none of the audit guidelines like the ISO 19011:2011 or standards like the ISO 9001:2015 explain the minimum percentage of samples to cover. However, it is explained in Annex B.3.1 of ISO 19011 Guidelines (P. 39) that "When sampling, consideration should be given to the quality of the available data, as sampling insufficient and inaccurate data will not provide a useful result...Audits can use either judgement-based sampling or statistical sampling". Also, it is addressed in Annex 3.3 of the same Guidelines (P. 39) that "When statistical sampling plan is developed, the level of sampling risk that the auditor is willing to accept is an important consideration". Subsequently, He (2016) addressed that to ensure that there is representativeness, an auditor must pay attention to randomness while drawing samples, but this randomness is not always effective and it may mislead the auditor (He, 2016). However, the authors of this paper believe that performing documentation review at early stage (prior to audit) may help the auditor to determine the most appropriate sampling method (judgement-based or statistical), thus, to search, look and hunt the samples almost correctly.

By performing assertions management and materiality assessment, the sampling will be much easier, more effective and will lead to proper diagnosis (PECB, 2016). Since it is not an easy task for any auditor to cover the whole processes of any audited department, it is recommended by the authors of this paper for the auditees to audit their processes/departments in advance by the form of self-auditing. The purposes of this self-auditing are: 1) to prepare for the main audit by identifying the issues and deficiencies that should receive the most attention, and then no need for the main auditor to waste a lot of time in detecting errors or risks that are commonly known, 2) to help the main auditor to audit and review further samples and audit evidence, and 3) to help the main auditor to enhance the audits' effectiveness and focus on the most important things. 
But the question is: has the idea of self-auditing been supported or justified by the standards and associated authors?

As long as the auditor might not be able to audit the most important matters of the audited process as a result of audit time pressure, Karapetrovic and Willborn (2002) proposed a model for conducting individual self-audits, where process owners have to conduct continuous self-audits in order to evaluate the performance of their processes. A problem with this approach is that the independence rule of auditing (ISO 19011, Clause 4.d), which states "auditors should be independent of the activity being audited wherever practical" is not met. Hence, organizations would find it difficult to implement this approach because a non conformity would be identified for violating this independence rule. Therefore, the relevant requirement of ISO 19011 auditor's independency will need be reviewed and reassessed, considering the statement of "wherever practical" that was identified in clause $4 . \mathrm{d}$ of ISO 19011:2011.

Taking into account that this independence rule is applicable to the internal audits (first party) and external audits (second party), whereas the ISO 19011 Guidelines are applicable to all of these types of audits.

This independency rule was also affirmed by Kimotho (2014, P. 145) who concluded that "internal audit independence is crucial to the institution to help to enhance accountability and performance". One of the bases of this conclusion seems to be the ISO 9001:2008 clause number 8.2.2 which stated explicitly that "the organization must select impartial and objective auditors and the people shall not audit their own work". Nevertheless, in the subclause 9.2.2.c of the latest version of ISO 9001:2015, the statement "not audit their own work" was omitted and the requirement in terms of Independency was changed and revised to be limited to "The organization shall select auditors and conduct audits to ensure objectivity and the impartiality of the audit process". Therefore, the authors of this paper believe that the intent of the independency rule is to ensure the objectivity and impartiality of the auditor and is not to prevent people auditing their own work.

For that reason, the authors of this paper advocate that the self-audit can be performed in the form of pre-audit or stage 1 audit because it is more about process performance, understanding and improvement than conformance checking. Then, it helps the auditor (during stage 2 audit) to audit performance rather than merely conformance.

But the other question that can be raised is: Can the auditee perform an effective self-audit on his/her process?

With a view to enhance and expand the role of auditor and auditees, the tool of coaching is proposed by the authors of this paper to be applied and integrated within the audit.

Coaching, as stated by Anderson (2013) is a useful way of developing people's skills and abilities and of boosting performance. It helps deal with issues before they become major problems.

Russell (2013) claims that the lead auditors should have the skills to direct and coach their audit staff (auditor team) and they should be careful not to tell the auditees how to complete their work or what decision to make, as there may be negative impact for the auditees. But the authors of this paper disagree with Russell (2013) concerning this restriction, because they believe that this restriction conflicts with Annex B.8.4 of ISO 19011:2011, that allow the 
auditor to guide the auditee on how to respond to the audit findings and this restriction may limit the added value roles of the auditor.

Clause 7.1.6 and Annex A.7 of the ISO 9001:2015 standard 'Organizational Knowledge' encourage organizations " $t o$ determine, manage and acquire knowledge in different ways, like mentoring".

To avoid directing auditees by auditors, the authors of this paper preferred to apply 'coaching' rather than 'mentoring' because the coach (auditor) can assist and encourage the auditees rather than direct them, and shall not prepare them to give the right or preferred answers.

Accordingly, in this paper, we will investigate how to enhance the role of auditor to include coaching of auditees, in addition to his task as a coach for the team of auditors. Since the coaching is a tool, and it is related to two main principles of the ISO 9001:2015 Standard out of seven quality management principles (Leadership and Involvement of People) the impact of its integration within auditing is determined in this paper.

\subsubsection{Incorporation of ISO 9001 Risk Based Thinking Concept Within Audit}

Swanson (2006, P. 5) pointed out that "audits are opportunities for companies to improve, based on auditor analysis and advice. To preserve the integrity and authority of audits, auditors maintain a delicate balance between offering advice and making decisions. According to "the role of internal audit in enterprise-wide risk management 'ERM'," by the Institute of Internal Auditors (IIA), the core internal audit role regarding ERM is generally to provide assurance that significant risks are being considered in day-to-day decision making. In providing this assurance, auditors evaluate risk efforts and discuss their findings with management. In addition to evaluating ERM efforts, auditors may also act as champions of ERM by helping managers to identify and evaluate risks, promoting the use of an ERM framework and advising managers on appropriate tactical and strategic risk management response".

Despite that this guideline is issued from the institute (IIA) that is related to management and financial auditors, but the content is related to Risk Management that is very important part of the Quality Audit.

By reporting the ten audit activities that were determined by Swanson (2006), it is revealed that most of them are interrelated with risk management, but they require provision of a risk management program (RMP). On the other hand, how should the auditor behave to cover the activities of risk management if there is no RMP available, as the situation in GMRA?

Deysher (2015, P. 8) identified that "the Risk Based Thinking Concept (RBTC) is embedded in two main principles of the ISO 9001:2015 Standard out of seven quality management principles (QMPs); It is an element in the process approach QMP and an element in the improvement QMP”; It should be taken into consideration that ISO 9001:2015 requirements are based on seven QMPs and consist of seven main clauses.

From this perspective, and as the auditing is a process, the integration of the two principles of 'Process Approach' and 'Improvement' within the auditing process will implicitly mean the integration of their RBTC. 
Consequently, the use of the latest version of the ISO 9001:2015 Standard as a model for auditing, implicitly means that the auditor is required to implement the RBTC at all phases of the audit.

Freeman and Drown (2015) recommend for the risk to be determined, implemented and effectively assessed prior to be registered and listed. While a formal record of risk analysis is not explicitly called for in the ISO 9001:2015 Standard, auditors may be looking for one and organizations may struggle to understand risk based thinking without it. Therefore, the authors of this paper agree with Freeman and Drown (2015) to determine the risks during the audits (internal and/or external) prior to be listed in the aimed formal Risk Management Program.

Sandle (2016) identified that one of the important aspects of the audit process is assessing risk. Risk-based internal auditing is a methodology that links internal auditing to an organization's overall risk management framework. When choosing the areas to audit, selections should not only focus on where the risk is high in terms of outcome, but also consider the degree of confidence in control measures that are applied by the auditees (Sandle, 2016).

As a result, it was determined in this research study whether the auditors can cover the role of risk assessment during their audits. Consequently, it will be found out how to enable the auditor to be Risk Assessor and then to be involved in risk management as recommended by Swanson (2006) and Sandle (2016).

\subsubsection{Involving the Auditors in Problem Solving}

With reference to section 1 and in particular to the complaint number ' $d$ ' of the selected organization, which states that "the current internal auditors have failed to make the auditees supporter instead of disbelievers of the audit process", the authors of this research study focus on the types of the added value that were addressed by PwC (2014, P.1) which provides the added value that is expected to be delivered by internal auditors, whose role include; assurance provider, problem solver, insight generator and trusted advisor. However, the value of "Problem Solver" may conflict with Russell (2013) who asserts that the lead auditors should be careful not to tell the auditees how to complete their work or what decision to make. This preventative measure might have been issued to act in accordance with clause 6.7 of 19011:2011 guideline, which states that "the corrective, preventive or improvement actions are usually decided and undertaken by the auditee". On the other hand, and from the other point of view, it is addressed in Annex B.8.4 of the same guidelines that "depending on the arrangements with the audit client, the auditor may guide the auditee on how to respond to those findings". Thus, the auditors may need to be aware of Annex B.8.4 of ISO 19011:2011 that implicitly allow them to be involved in solving the problems discovered during audit by finding and removing the causes of these problems. As a result, the authors of this paper involved in the determination of the root causes of audit findings, in order to examine the expected added value of 'problem solver'. Bearing in mind that this recommendation is applicable for both internal and external audit because it is identified in clause 1 (Scope) of the ISO 19001:2011 Guideline (P. 1) that "it is applicable to all organizations that need to conduct internal or external audits of management systems or manage an audit program."

\subsubsection{Integrating the Methodologies that Lead to Improvement Within Audit}


Generally, this integration is undertaken through utilization of the methodologies that lead to the improvement of the whole quality management system (QMS) and enhanced performance. The integration of Lean Six Sigma (LSS) methodologies were found appropriate by Barlow (2013) who demonstrated how Lean tools can be integrated into current audit methodology, as the accomplishment of this integration will allow Lean tools to give auditors the ability to drill deeper and wider in looking for weaknesses in business systems, in addition to non conformance to the existing QMS. Thereafter, Coleman (2015) demonstrated how the lean and six sigma related tools can be integrated into current audit methodology in order to develop more robust, value added, and continuous improvement driving from internal audit program. Smoth (2016) also showed that lean six sigma related tools can be utilized to improve audit planning, implementation, corrective and preventive action and follow up activities, and he demonstrated that the DMAIC (define, measure, analyze, improve, control processes from 6 sigma) and the PDSA (plan, do, study and act processes from Lean) can be very effective during all the phases of audit. To ensure improving of the audit process itself, the auditors need to ensure to close the PDSA cycle.

Whereas the above recommendations of Barlow (2013), Coleman (2015), and Smoth (2016) helped to manage risk by minimizing waste and errors, it was reported by Smoth (2016) that this integration has also some limitations. These limitations include: 1) the need for a significant amount of statistical data gathering and analysis and skilled people, 2) the needs to apply the methodology of LSS and a program for risk management.

Also, Since the integration of RBTC and LSS helped to manage risk and led to improvement, and as long as the improvement is one of the ISO 9001:2015 seven principles, and the RBTC is part of this principle, it becomes important and advantageous to find further tools that are related to the seven ISO 9001:2015 principles collectively.

Therefore, the aim of this paper is to propose an auditing framework that has the potential to utilize ISO 9001 standard in a different way of auditing. This way is explored through utilizing the seven principles of ISO 9001:2015 within audits.

Taking into account that the recommendations of Barlow (2013), Coleman (2015), and Smoth (2016) provide insights and/or contributions to improve the auditing process, but this paper provides contributions to audit the concept of Improvement at the audited process by using the relevant management tools during this audit.

\subsection{Research Inspiration}

Whereas, the development of the framework is the aim of this research, these authors decided to learn from the experience of business excellence models (BEMs) implementers in development of the performance measurement (PM) frameworks and in converting the concepts and principles into practice.

Remembering that the BEMs have already focused attention on the concepts and principles at earlier stages than the ISO 9001:2015. Furthermore, the recognition by EFQM (2016) that the concepts of its excellence model and the principles ISO 9001:2015 are interrelated and they can complement each other was one of the basis of the idea for developing an auditing framework on the principles of the ISO 9001:2015 Standard. 
Also, as a result of the added value that was gained by Boeing Aerospace from its integration of the management tools within the 4P Model to develop a business excellence framework (BEF) as reported by Dahlgaard, Chen, Jang, Banegas and Dahlgaard Park, 2013), it has been determined in this research study, how can the ISO 9001:2015 Standard better offers itself good opportunities to be used in the ways of self assessment using BEF by utilizing and integrating its principles through their relevant management tools within auditing, and how does this utilization help to overcome the customer complaints and audit limitations that were reported earlier in sections 1 and 2.1 respectively. In their analysis of Boeing Aerospace, Dahlgaard et al. (2013) reported that the company not only uses a BEM (like the MBNQA) to guide their operations, but also uses a variety of management tools and techniques in its operation.

Remembering that all of these recommendations do not conflict with the ISO Publication (2015) which speculated that the QMPs of ISO 9001 can form a basis for performance evaluation. Thus, the key to the riddle is the tools that should be selected and integrated within the audit.

For the purpose of identifying the most important tools that can be integrated within the aimed auditing framework, the following criteria were developed by these authors based on the results of their literature review and customer complaints. These criteria require that the selected tools ought to be:

- $\quad$ related to the seven QMPs of ISO 9001:2015 severally or collectively

- $\quad$ related to the ISO 9001:2015 concepts of Plan, do, check and act (PDCA) and risk based thinking (RBT).

- $\quad$ synergistic to the audit pillars of conformance, performance, improvement and risk management.

- $\quad$ integrated within auditing at its different phases, which include planning, execution, data gathering, data interpretation and follow up.

- $\quad$ learned, understood and handled easily by auditors.

- $\quad$ implemented with no or minimum cost impact.

- $\quad$ used in problem identification, problem solving and analysis of audit evidence and audit findings.

- $\quad$ used without a need for significant amount of statistical data gathering and analysis.

- $\quad$ used without a need for implementing risk management program or lean six sigma program.

Applying these criteria resulted in selection of the twelve management tools identified below in Table II.

\begin{tabular}{|c|c|c|}
\hline \multicolumn{2}{|c|}{ Table 2 of 12} \\
\hline $\begin{array}{c}\text { ISO } \\
\text { 9001:2015 } \\
\text { Principle }\end{array}$ & $\begin{array}{c}\text { The selected related } \\
\text { management tools }\end{array}$ & $\begin{array}{c}\text { Examples of the targeted audit limitations and customer } \\
\text { complaints }\end{array}$ \\
\hline
\end{tabular}




\begin{tabular}{|l|l|l|}
\hline $\begin{array}{l}\text { Customer } \\
\text { Focus }\end{array}$ & $\begin{array}{l}\text { 1-Customer partnership. } \\
\text { 2- Internal customers } \\
\text { segmentation. }\end{array}$ & $\begin{array}{l}\text { 1- Obtaining insignificant audit findings as a result of auditing } \\
\text { people (auditees) who are incompetent and unskilled with regard to } \\
\text { the roles that have been delegated to them by ISO 19011 Guidelines. } \\
\text { 2- Imperfect recognition/identification of the internal customer of } \\
\text { the audited process. }\end{array}$ \\
\hline Leadership & $\begin{array}{l}\text { 3-SWOT (Strength, } \\
\text { weakness, opportunities } \\
\text { and threats). } \\
\text { 4- PEST (Political- } \\
\text { Economic and Socio- } \\
\text { Technology). }\end{array}$ & $\begin{array}{l}\text { 3- Non determination of the threats, risks and opportunities at the } \\
\text { audited process. } \\
\text { 4- Failing to identify many warning indicators with regard to } \\
\text { technical failures. }\end{array}$ \\
\hline
\end{tabular}




\begin{tabular}{|c|c|c|}
\hline $\begin{array}{l}\text { Engagement of } \\
\text { people }\end{array}$ & 5-Coaching. & $\begin{array}{l}\text { 5-Failure to involve people in the } \\
\text { continual improvement process. } \\
\text { 6- Limited resources of internal } \\
\text { auditors. } \\
\text { 7- Insufficient awareness of the auditee } \\
\text { team to the ISO } 9001 \text { Standard and ISO } \\
\text { 19011 Guidelines. }\end{array}$ \\
\hline $\begin{array}{l}\text { Process approach } \\
\text { (including RBTC) }\end{array}$ & $\begin{array}{l}\text { 6- 5Ms (Manpower, Machine, Method, } \\
\text { Measure, Material). }\end{array}$ & $\begin{array}{l}\text { 8-No added value in terms of } \\
\text { performance. } \\
\text { 9- Failing to identify audit findings and } \\
\text { their causes correctly and accurately. }\end{array}$ \\
\hline $\begin{array}{l}\text { Improvement } \\
\text { (including RBTC) }\end{array}$ & $\begin{array}{l}\text { 7- Problem definitions by } 4 \mathrm{Ws}, 2 \mathrm{Hs}, 1 \mathrm{C} \text { (What, } \\
\text { Where, When, Who, How much, How often } \\
\text { and What Consequences). } \\
\text { 8- Determination of NC Causes by use of } 5 \mathrm{Ms} \\
\text { and } 5 \text { whys. } \\
\text { 9- Determination of NC Causes by use of RCA } \\
\text { (Root Cause Analysis). }\end{array}$ & $\begin{array}{l}\text { 10- Failure to prevent recurrence of } \\
\text { problems. } \\
11 \text { - No added value in terms of } \\
\text { improvement. }\end{array}$ \\
\hline $\begin{array}{l}\text { Evidence based } \\
\text { decision making }\end{array}$ & $\begin{array}{l}\text { 10- PDCA (Plan, Do, Check and What). } \\
\text { 11- Prioritization. }\end{array}$ & $\begin{array}{l}\text { 12- Not auditing the most important } \\
\text { matters. } \\
\text { 13- Inadequacy of audit samples. } \\
\text { 14- Use of immaterial audit evidence as } \\
\text { a base for making decision. }\end{array}$ \\
\hline $\begin{array}{l}\text { Relationship } \\
\text { Management }\end{array}$ & 12- Value of supplier partnership. & $\begin{array}{l}\text { 15- Limitation of audit time. } \\
\text { 16-Audit discontinuity. } \\
\text { In addition to the limitations } 1 \text { and } 2 .\end{array}$ \\
\hline
\end{tabular}

Table II shows examples of the targeted audit limitations and customer complaints. For example, the ISO 9001 principles: "Leadership, Engagement of People, and Evidence based decision making " can be related to the management tools: "SWOT (Strength, weakness, opportunities and threats) / PEST (Political-Economic and SocioTechnology), Coaching and Prioritization" that can be related to the audit problems and imitations: (1) Failing to identify many warning indicators with regard to technical failures, despite the fact that all of the technical procedures have already been prepared and reviewed by well-known and internationally accredited firms, and 2) Not auditing the most important matters, and 3) Use of immaterial audit evidence as a base for making decision).

Table III shows how the seven QMPs of ISO 9001:2015 can be realized by means of the management tools and shows at which phase of audit these tools can be integrated. As a result, a conceptual auditing framework (CAF) was developed, it shows where, when and how these tools are to be used and in a certain sense, it shows how the selected management tools are embedded and dispersed into the phases of the audit. This framework is illustrated below in Table III. 


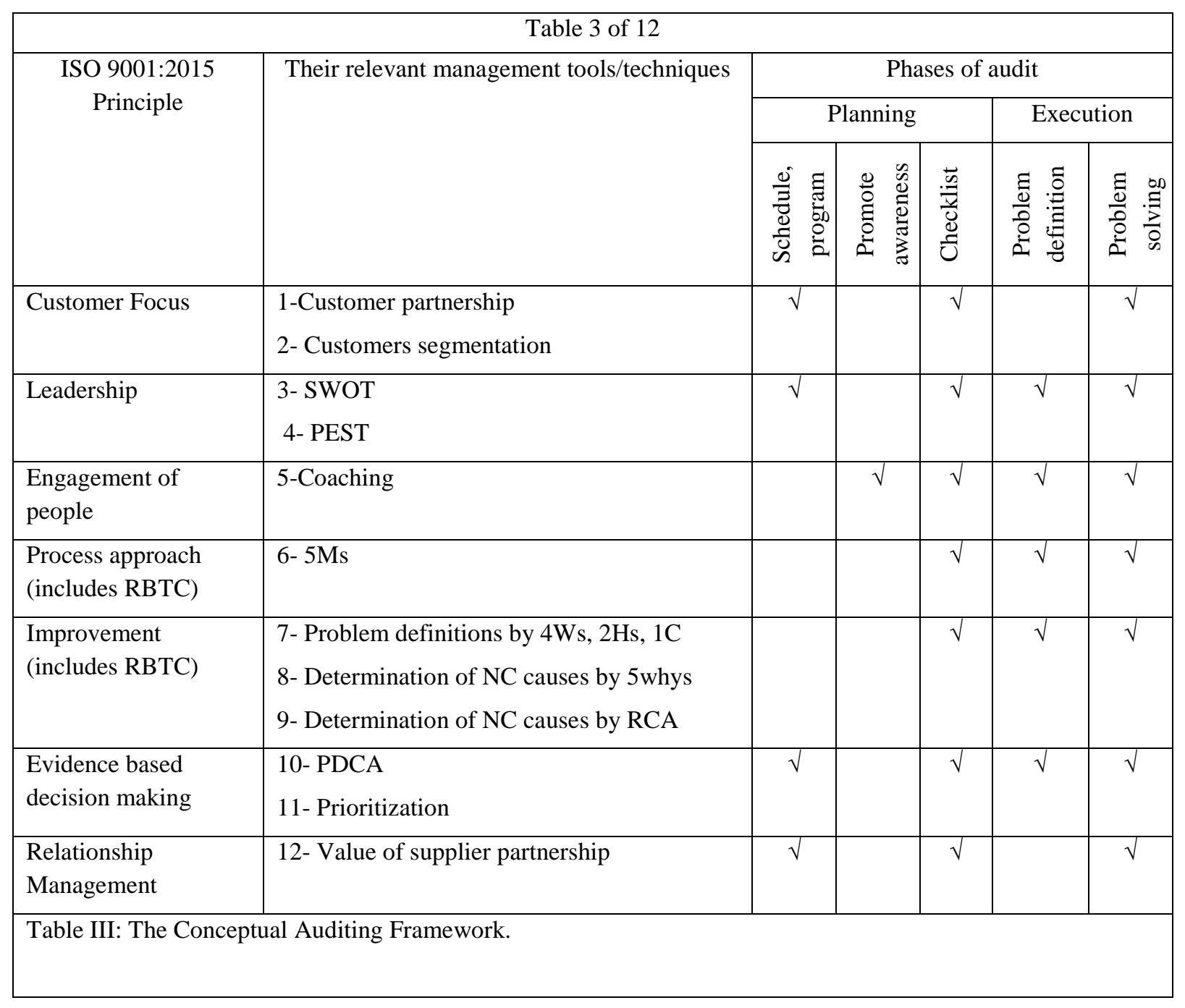

Taking into account the results of the previously approved documentation review, complaints and practical needs of the selected organization (GMRA), a preliminary auditing framework (PAF) was developed by these authors based on the CAF.

\subsection{Development of Preliminary Auditing Framework (PAF)}

The first version of this PAF consisted of 132 questions and guidelines. This PAF was thoroughly tested and validated by a further mixed methods study including eleven internal audits, two management reviews (MR) and three workshops. Also, the ISO 9001 Standard and its related guidelines were reviewed to determine the gap in relation to the enhancement of the audits of this study and its PAF. After completing this practical work, this PAF was evaluated against the results of data analysis, in order to be revised to its final version (Table XII). The stages of this development are shown below in Fig. 1. 


\section{Conceptual Auditing Framework (CAF)}

To be reviewed against the results of documents review, complaints and practical needs of the concerned organization

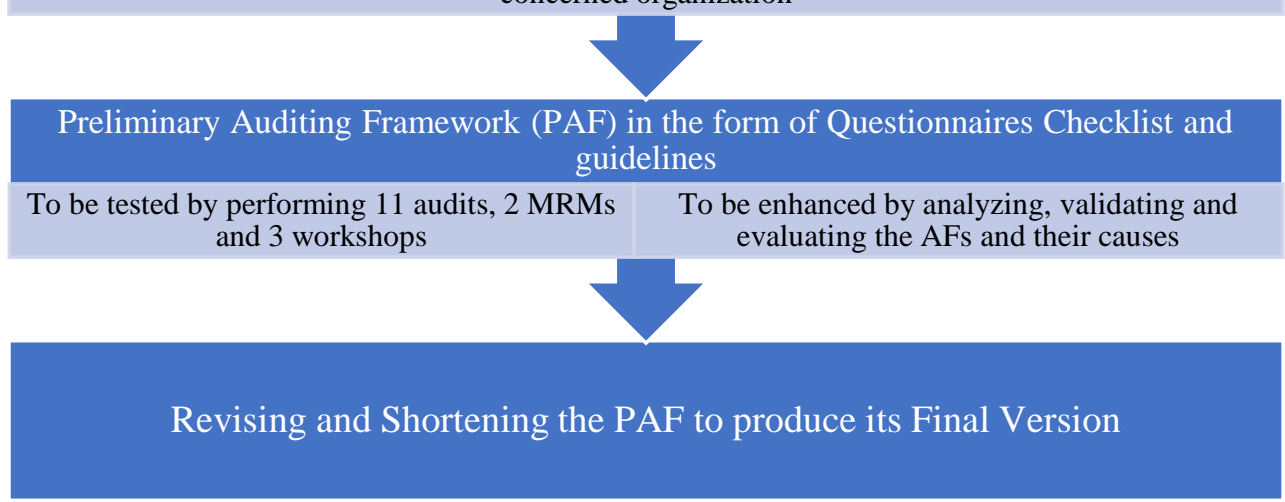

Fig. 1: Stages of Auditing Framework Development.

The contents of the final version of this PAF are shown later in section 6.2 (Table XII).

\section{$3 \quad$ Research Methodology}

\section{$3.1 \quad$ Sample Selected}

As identified earlier in section 2.1 that the complaints and practical needs of GMRA were analogous with the audit's limitations that were identified by the literature review, this organization (GMRA) has been selected to be the sample of this research study. This sample is represented here by the five departments that cover the main and core business processes. The selected five departments were represented by their managers, who are supposed to be fully aware of the technical/management details, problems and threats of their departments and who can get the necessary support from their staff easily. Also, these five department managers were chosen because they comprise the most important departments who form the members of the emergency committee and who are fully responsible for organization's management and operation during emergencies and crises.

Eleven audits were performed at the selected five departments. Each department (participant) was audited two times, the first audit was in the form of self-audit (stage 1) and the second one was in the form of the main audit (stage 2 audit).

Stage 1 audits were conducted by the auditees (participants) by means of self-auditing by using the audit tool of the first version of the PAF. All of stage 2 audits were conducted by the first author of this paper who is Certified Senior Lead Auditor at the same five departments by using the same audit tool (PAF).

Thereafter, all of the five departments (participants) were audited in combination by the first author of this paper. 
To verify selecting the right participants, it was assured that each participant of the selected five samples has already been subjected to one-week training course related ISO 9001 Quality Auditing and each one of them represents a customer for another participant and a supplier for other. Malsbury (1999) advocated that the audit client should be the customer of the audited process, not the top management. The selected departments are shown in Table IV.

\begin{tabular}{|l|l|l|}
\hline \multicolumn{2}{|c|}{ Table 4 of 12 } \\
\hline $\begin{array}{l}\text { (It is a customer for Department } \\
\text { 2) }\end{array}$ & $\begin{array}{l}\text { Department 2 } \\
\text { (It is a customer for Department 1 } \\
\text { and a supplier for Department 3) }\end{array}$ & $\begin{array}{l}\text { (It is a customer for Department 2 } \\
\text { and a supplier for Departments 4 } \\
\text { and 5) }\end{array}$ \\
\hline Pipeline Inspection Techniques & Corrosion Protection & Operation and Maintenance \\
\hline
\end{tabular}

\begin{tabular}{|l|l|}
\hline Department 4 & Department 5 \\
$\begin{array}{l}\text { (It is a supplier and a customer for Departments1, } \\
\text { 2 and 3) }\end{array}$ & $\begin{array}{l}\text { (It is a supplier and a customer for Departments } \\
1,2 \text { and 3) }\end{array}$ \\
\hline Technical Affair & Safety \\
\hline Table IV: Determination of The Auditees Team.
\end{tabular}

Thereafter, the results of these audits were analyzed in accordance to the scope of the practical work that is shown in Fig. 2.

\subsection{Steps of The Practical Work}

The steps of the practical work are shown below in Fig. 2. The data analysis in this research starts in parallel with the data collection. 
Gap analysis and LR to determine the research aim and the most appropriate management tools that are consistent with ISO 9001:2015 QMPs and that can be integrated within auditing.

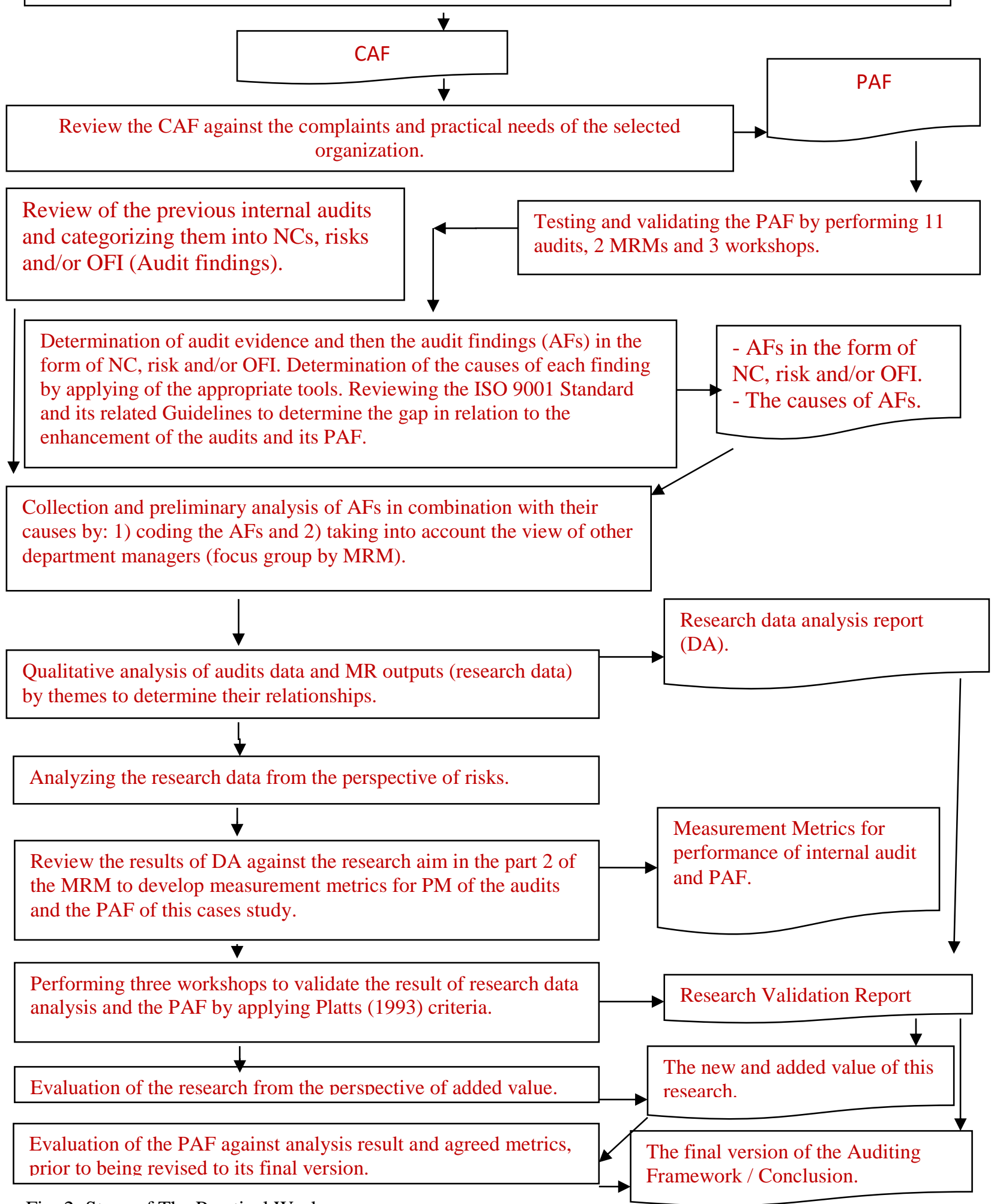

Fig. 2: Steps of The Practical Work 
The methods of the research data collection, analysis, validation and evaluation are illustrated below in Tables $\mathrm{V}$, VI, VII and VIII respectively.

\subsection{Methods of Data Collection (DC)}

The methods of research data collection are shown below in Table V.

\begin{tabular}{|c|c|c|c|}
\hline \multicolumn{4}{|c|}{ Table 5 of 12} \\
\hline NO. & DC Method & $\begin{array}{c}\text { Documents reviewed } \\
\text { and people interviewed }\end{array}$ & Objective \\
\hline 1 & Literature Review & $\begin{array}{l}\text { All documents } \\
\text { identified below in the } \\
\text { References, and all } \\
\text { people identified here in } \\
\text { section } 3\end{array}$ & $\begin{array}{l}\text { To identify the limitations of the } \\
\text { performance measurement (PM) } \\
\text { methodologies by ISO 9001 quality } \\
\text { audit and self assessment using } \\
\text { business excellence models (BEMs) } \\
\text { that were experienced by different } \\
\text { organizations, as reported in literatures. } \\
\text { To determine the audit program } \\
\text { strategies that were reported in } \\
\text { literatures to overcome these audit } \\
\text { limitations } \\
\text { To design the conceptual auditing } \\
\text { framework }\end{array}$ \\
\hline 2 & Documentation Review & $\begin{array}{l}\text { The results of GMRA } \\
\text { previous internal audits, } \\
\text { and certification audit }\end{array}$ & $\begin{array}{l}\text { To determine the weaknesses and } \\
\text { limitations of audit in the sample } \\
\text { selected. } \\
\text { To design the preliminary auditing } \\
\text { framework }\end{array}$ \\
\hline 3 & Documentation Review & $\begin{array}{l}\text { The relevant audit } \\
\text { standards and } \\
\text { guidelines, such as the } \\
\text { ISO 9001:2015 } \\
\text { Standard and the ISO } \\
\text { 19011:2011 Guidelines. }\end{array}$ & $\begin{array}{l}\text { To determine whether the new version } \\
\text { of standard i.e. ISO } 9001: 2015 \text { covered } \\
\text { the audit limitations and strategies that } \\
\text { have been covered by the associated } \\
\text { authors befoe issue of this standard, } \\
\text { and to what extent. }\end{array}$ \\
\hline 4 & Audits (11) & $\begin{array}{l}\text { The Managers of the } \\
\text { selected five } \\
\text { departments }\end{array}$ & $\begin{array}{l}\text { To test the proposed preliminary } \\
\text { auditing framework }\end{array}$ \\
\hline 5 & $\begin{array}{l}\text { Focus group in the form of } \\
\text { Management review meeting } \\
\text { (2) }\end{array}$ & $\begin{array}{l}\text { The Managers of the } \\
\text { selected five } \\
\text { departments and other } \\
\text { departments }\end{array}$ & $\begin{array}{l}\text { To validate the proposed preliminary } \\
\text { auditing framework and the results of } \\
\text { audits }\end{array}$ \\
\hline 6 & $\begin{array}{l}\text { Focus group in the form of } \\
\text { Workshops (3) }\end{array}$ & $\begin{array}{l}\text { The five auditees and } \\
\text { five internal auditors }\end{array}$ & $\begin{array}{l}\text { To validate, analyze and evaluate of } \\
\text { the proposed preliminary auditing } \\
\text { framework and the results of audits }\end{array}$ \\
\hline & Table V: Methods of Data C & ion & \\
\hline
\end{tabular}


Table V Shows the samples of documents reviewed and people interviewed at each stage of Data Collection. Concerning the data collection method number 4 (auditing), it is imports to know that in this research study, the type of each audit was a combination of system audit and process audit in order to verify the effectiveness of the management system (MS) by using the process techniques and to avoid any risk of gathering inappropriate data, as recommended by (Russell, 2013).

\subsection{Methods of Data Analysis (DA)}

The methods of research data analysis are shown below in Table VI.

\begin{tabular}{|c|c|c|}
\hline \multicolumn{3}{|c|}{ Table 6 of 12} \\
\hline No. & DA Method & Objective \\
\hline 1 & $\begin{array}{l}\text { Analysis of audit findings and their causes by } \\
\text { taking into account the view of other department } \\
\text { managers (focus group by MRM part } 1 \text { 'group } \\
\text { interview). }\end{array}$ & $\begin{array}{l}\text { To assure the reliability and validity (credibility } \\
\text { and trustworthiness) of the data that was } \\
\text { collected. }\end{array}$ \\
\hline 2 & $\begin{array}{l}\text { Analysis of audit findings by taking into } \\
\text { accounts the causes and effects. }\end{array}$ & $\begin{array}{l}\text { To verify the materiality, validity, correctness } \\
\text { and accuracy of the discovered audit findings and } \\
\text { their root causes. }\end{array}$ \\
\hline 3 & $\begin{array}{l}\text { Analysis of research data (audits data and MR } \\
\text { data) by themes (Qualitative Contents Analysis). }\end{array}$ & $\begin{array}{l}\text { To analyze the findings against the purpose of } \\
\text { this paper, which include assisting the } \\
\text { organizations that experience difficulties with the } \\
\text { current ISO } 9001 \text { audits to achieve their planned } \\
\text { objectives with regard to their auditing of } \\
\text { conformance, performance, risk management and } \\
\text { improvement collectively }\end{array}$ \\
\hline 4 & $\begin{array}{l}\text { Analysis of research data from the perspective of } \\
\text { risk. }\end{array}$ & $\begin{array}{l}\text { To analyze the findings against the rationale of } \\
\text { this paper, which include: none of technical } \\
\text { failures were predicted by any of the internal or } \\
\text { external audits conducted during that period }\end{array}$ \\
\hline \multicolumn{2}{|c|}{ Table VI: Methods of Data Analysis } & \\
\hline
\end{tabular}

To assure the reliability and validity of the data that was collected and analyzed, the auditor (first author) focused only on the audit findings (NCs, risks and opportunity for improvement 'OFI') that are shown in Fig. 3. 


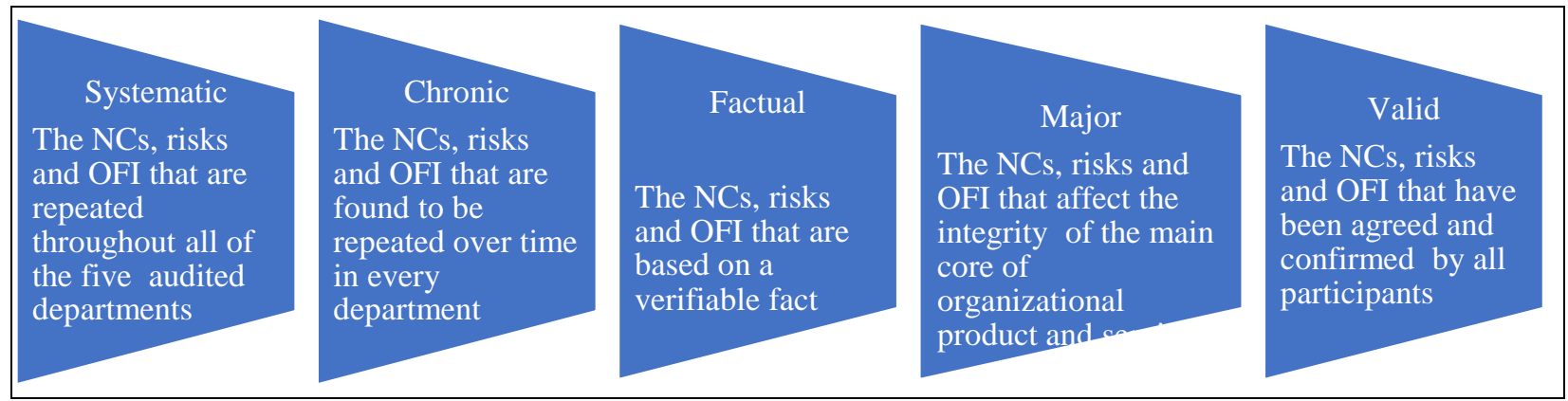

Fig. 3: Types of Audit Findings.

The materiality, validity, correctness and accuracy of the discovered audit findings and their root causes were verified by involving the auditor in this determination and by applying the appropriate management tools that are shown below in Fig. 4.

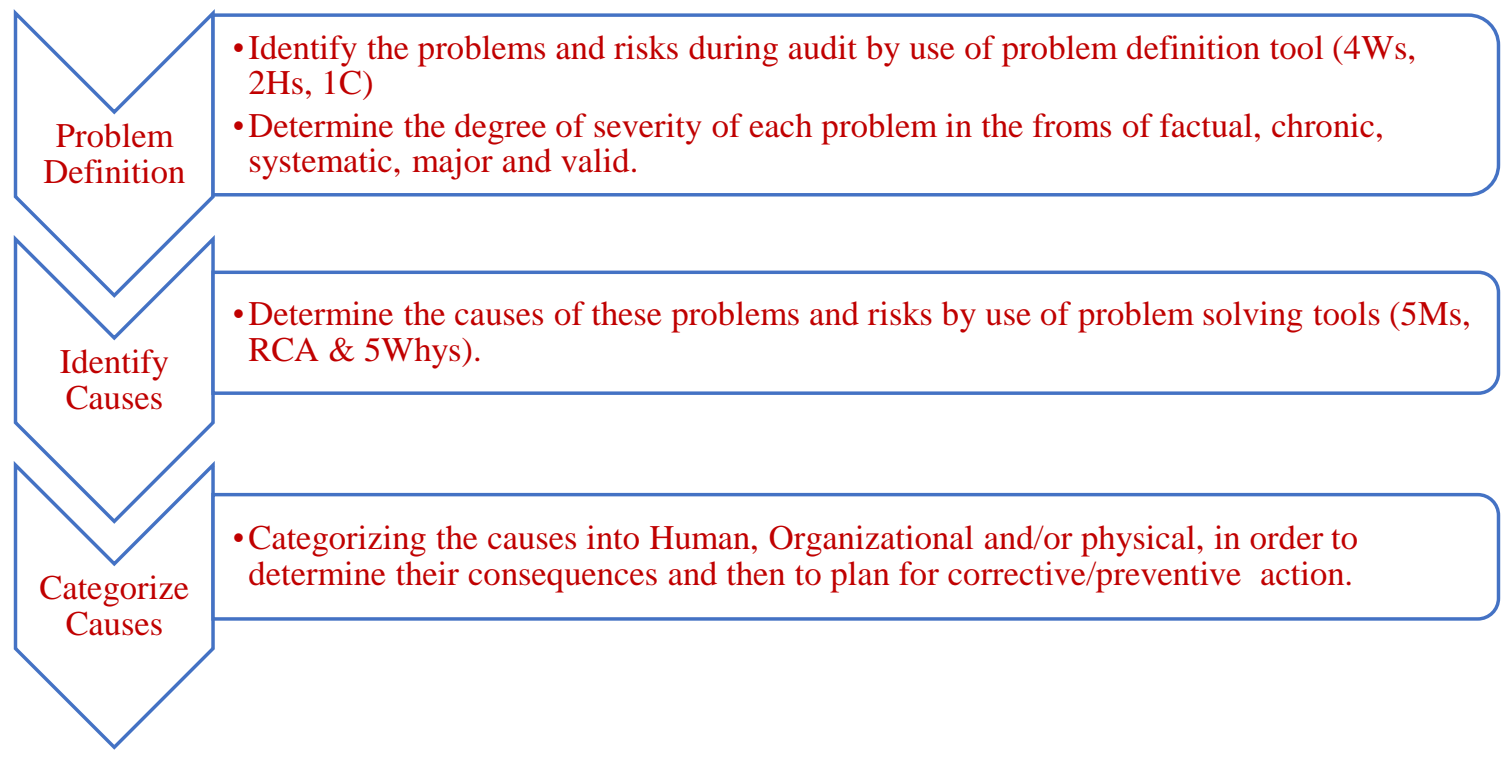

Fig. 4: Determination of AFs causes.

By applying the 5Ms, the determined causes were divided into Human (Manpower), Organizational (System, Method, Measures, Software and Procedures) and/or Physical (Machine, Materials and structure), as it is illustrated in Fig. 5. 


\section{Human}

Competence, skills, experience, knowledge and awareness
Organizational

Management System, Method,

Measures, Software, Procedures

and Work Plans

\section{Physical}

Machine, Materials, structure,

finished product, technology and specifications

Fig. 5: Categorization of Causes by their Types.

\subsection{Analysis of the Research Data by Themes}

The audits findings (output of DC method number 4 of Table V) and the output of the two management review meetings (DC method number 5 of Table V) were thematically determined and interpreted to look for relationships between them. The interrelation and links between each of the determined themes were manifested in the following form of Table VII.

\begin{tabular}{|l|l|l|}
\hline \multicolumn{2}{|c|}{ Table 7 of 12 } \\
\hline Theme & Its Definition in this research study & \\
\cline { 2 - 2 } & indicators of its effectiveness & \\
\hline & Relationship with \\
\hline
\end{tabular}

The authors of this paper built the credibility of their research by testing the analyzed data and its PAF by the validation and evaluation methods that are shown below in Table VIII.

\begin{tabular}{|l|l|l|}
\hline \multicolumn{2}{|c|}{ Topic } & \multicolumn{1}{|c|}{ Method 8 of 12 } \\
\hline $\begin{array}{l}\text { Validation of } \\
\text { the research } \\
\text { data }\end{array}$ & Triangulation. & $\begin{array}{l}\text { Triangulation was used by evaluating the } \\
\text { audit evidence and audit findings. }\end{array}$ \\
\hline $\begin{array}{l}\text { Validation of } \\
\text { the aimed } \\
\text { auditing } \\
\text { framework }\end{array}$ & $\begin{array}{l}\text { Testing the feasibility, usability and utility of } \\
\text { the auditing framework (Platts 1993). } \\
\text { The auditees and further five internal auditors } \\
\text { were called to attend three workshops, in order } \\
\text { to answer and comment on the following } \\
\text { questions that were formulated from Platts } \\
\text { (1993) evaluation criteria: }\end{array}$ & $\begin{array}{l}\text { To review and revise the first version of the } \\
\text { PAF to its final version }\end{array}$ \\
& $\begin{array}{l}\text { a- Feasibility: Could the process be followed? } \\
\text { b-Usability: How easily could the process be } \\
\text { followed? } \\
\text { c-Utility: Was the process useful? }\end{array}$ & \\
\hline
\end{tabular}




\begin{tabular}{|l|l|l|}
\hline $\begin{array}{l}\text { Evaluation } \\
\text { Method (Stage } \\
1)\end{array}$ & $\begin{array}{l}\text { 1- Evaluation of the results of research data } \\
\text { analysis from the perspective of added value. }\end{array}$ & $\begin{array}{l}\text { 1- To revise the PAF to its final version. } \\
\text { 2-To determine the contribution of this } \\
\text { research to the body of knowledge and } \\
\text { practice. }\end{array}$ \\
\hline $\begin{array}{l}\text { Evaluation } \\
\text { Methods (Stage } \\
2)\end{array}$ & Realizing the research aim. & $\begin{array}{l}\text { To guide the conclusion of this research } \\
\text { study. }\end{array}$ \\
\hline
\end{tabular}

Table VIII: Methods of Research Data Validation and Evaluation

\section{$4 \quad$ Results}

Prior to analyzing the audit findings and their causes that were resulted from the application of the proposed PAF, it was significant to consider the results of the previous internal audits and certification audit.

Knowing the proportions, percentages, natures and types of the discovered AFs and their causes of the previous and current audits has a significant impact on how these data are analyzed. Also, it shows the effectiveness of each stage of audits and the reasons for the difference and contrast between these stages (previous internal audits, stage 1 audits and stage 2 audits).

\subsection{Results of Previous Internal Audits and Certification Audit of the year 2016}

The results of previous internal audits and certification audit of the year 2016 are summarized below in Table IX.

\begin{tabular}{|c|c|c|c|}
\hline \multicolumn{4}{|c|}{ Table 9 of 12} \\
\hline Results and causes & Total Non conformities & $\begin{array}{c}\text { Non conformities raised } \\
\text { during internal audits }\end{array}$ & $\begin{array}{c}\text { Non conformities raised by } \\
\text { the certification body }\end{array}$ \\
\hline Results & 32 & 28 & 4 \\
\hline Causes & Documentation violation & Documentation violation & Documentation violation \\
\hline \multicolumn{4}{|l}{} \\
Table IX: Results of Previous Internal Audits and Certification Audit 2016. \\
\hline
\end{tabular}

All of the audit findings of the previous internal audits ( $28 \mathrm{NCs})$ and certification audit (4 NCs) were:

- $\quad$ limited to the non fulfillment of requirements (total 32) which mean that they cover audit of conformance.

- $\quad$ categorized factual. Only 9 of them out of a total of 32 were classified as chronic and systematic. 


\subsection{Results of Stage 1 Audits (Self-Auditing)}

The stage 1 audits resulted in determination of $24 \mathrm{NCs}$ (50\% of them are categorized as risks) with their causes, which were as follows:

- $\quad 15$ causes are Organizational.

- $\quad 5$ causes are Human.

- $\quad 3$ causes are Organizational and Human.

- 1 cause is Physical.

\subsection{Results of Stage 2 Audits}

The stage 2 audits resulted in determination of $46 \mathrm{NCs}$ ( $48 \%$ of them are categorized as risks) with their causes, which were as follows:

- $\quad 22$ causes are Organizational and Human.

- 10 causes are Organizational.

- 8 causes are Human.

- 3 causes are Physical.

- $\quad 3$ causes are Human and Physical.

\section{Discussion and Data Analysis}

\section{$5.1 \quad$ Auditing of Conformance}

By reviewing the results of previous internal audits and certification audit that are summarized in Table IX, it is revealed that auditing of conformance was realized by GMRA previous internal audits, and the effectiveness of these audits with regard to conformance is demonstrated because all of the discovered NCs were issued in cases where the requirements are not followed. However, GMRA may fail to achieve its objectives in terms of their auditing of performance, risk management (RM) and improvement, as none of the discovered audit findings are related to these approaches.

\subsection{Auditing of Performance}

Auditing of Performance was realized by implementing the PAF through the following interpretations:

i- 43 NCs out of the discovered 46 NCs during stage 2 audits were issued in cases where the requirements related to an intended or specified use are not followed, and where the ineffectiveness is demonstrated.

ii- Auditing the most important matters. 100\% of the discovered 70 AFs were major, valid, systematic, chronic and factual, and they are related to the core business processes and they affect the integrity and reliability of the main core of organizational product (pipeline and infrastructures) and also process effectiveness. 
iii- Performing stage 1 audits (self-auditing) led to discovering further AFs during stage 2 audits. The range of audit evidence and audit samples that were covered during stage 2 audits (which led to discovering 46 AFs) were wider and more than the samples that were covered by stage 1 audits (which led to discovering $24 \mathrm{AFs}$ )

iv- Determining the causes of all AFs easily. Most AFs and their causes were discovered by involving the auditors in problems solving; and by using plurality of problem solving tools, such as the RCA, 5Whys and 5Ms.

Therefore, these results revealed that the organizations in order to audit their performance, they need to: involve their auditors in problem solving by using plurality of problem solving tools; induce their auditors to attain the skills needed for assertion and sampling; and perform pre-audits in the form of self-auditing.

\subsection{Auditing of risk management}

Auditing of risk management was realized by implementing the PAF through the following interpretations:

i- The total results of stage 1 and stage 2 audits revealed that they were effective in identification of 34 risks out of a total of $70 \mathrm{AFs}(49 \%)$.

ii- The stage 1 audits (self-auditing) were effective in helping the auditor of stage 2 audits to focus on the most important matters from the perspective of risk. This is relied on the discovery of 24 AFs during stage 1 audit led up to discovery of further 46 AFs during stage 2 audits and $50 \%$ of these 46 AFs were about risk identification.

iii- The group interview by the management review meeting was effective in identifying and addressing the types of consequences of the risks identified. The auditor and auditees have successfully determined the types of consequences for 19 risks out of a total of 22 risks of stage 2 audits. Herein in Table X are the types of consequences which have been identified and categorized as high severity and high probability.

\begin{tabular}{|c|c|}
\hline \multicolumn{2}{|r|}{ Table 10 of 12} \\
\hline $\begin{array}{l}\text { AF serial number of stage } 2 \\
\text { audit, that identified risks }\end{array}$ & Their Types of Consequences \\
\hline $\begin{array}{l}1,2,3,5,6,8,27,28,29,36 \\
\text { (total } 10 \mathrm{AFs} \text { ) }\end{array}$ & $\begin{array}{l}\text { Technical failures, like pipeline failure due to consuming of corrosion } \\
\text { protection sacrificial zinc anodes. }\end{array}$ \\
\hline $\begin{array}{l}1,2,3,5,6,8,13,14,15,16,17 \\
18,27,28,29 \& 36 \text { (total } 16 \mathrm{AF})\end{array}$ & $\begin{array}{l}\text { Failure in technology, like lack of efficiency of the acoustic monitoring } \\
\text { techniques that are used for monitoring of pipeline integrity. }\end{array}$ \\
\hline $\begin{array}{l}1,2,3,4,5,9,13 \text { and } 36 \text { (total } 8 \\
\text { AFs) }\end{array}$ & $\begin{array}{l}\text { Problems in overall system, like loss of control in many processes including } \\
\text { the process of performance measure and process of internal audits. }\end{array}$ \\
\hline $\begin{array}{l}1,2,3,5,8,13,27,28,29 \text { and } \\
36 \text { (total } 10 \mathrm{AFs} \text { ) }\end{array}$ & $\begin{array}{l}\text { Breakdown of some of project permanent equipment like, water wells } \\
\text { pumps, degassing plants, water treatment plants, pressure relief valves, } \\
\text { butterfly valves, header tanks, water balancing reservoirs, } \\
\text { telecommunication system, air evacuation units, electric generators, etc. }\end{array}$ \\
\hline 5,7 and 36 (total $3 \mathrm{AFs})$ & $\begin{array}{l}\text { Financial crises and termination of cash flow that was routinely provided by } \\
\text { the government. }\end{array}$ \\
\hline $\begin{array}{l}6,7,14,15,16,17,18 \text { and } 36 \\
\text { (total } 8 \mathrm{AFs} \text { ) }\end{array}$ & Economic crises, due to loss of customers who buy and utilize GMRA water. \\
\hline Table X: Type of Consequences & \\
\hline
\end{tabular}


These results illustrated that most types of risk's consequences are interrelated to technical and technological failures (physical), and they were categorized critical because they are related to the main product of the audited processes (pipeline integrity). By comparing these consequences with the problem identification rationale (section 1), it is revealed that these audits were effective in responding to customer complaint ' $\mathrm{b}$ ', which states; "The audits have failed to identify many warning indicators with regards to technical failure". Therefore, these audits helped to predict how each part of the system might fail, but the mechanisms that might produce these modes of failure could not be determined.

iv- Interviewing more participant including the of owner/operator/customer of the audited processes and the managers of the other departments helped in determination of the consequences of the detected risks, but more work would be needed to determine their probabilities and severities. Applying further tools like Failure Mode Effect Analysis (FMEA) in the audited process during the time of audit would need to be investigated by further study, in order to determine whether this application would help the auditor to audit the cycle of risk management completely (risk determination, assessment, analysis and management), and help the auditee to start applying or update the FMEA at his/her process.

The discovery of 34 risks out of a total of $70 \mathrm{AFs} \mathrm{(49 \% )} \mathrm{and} \mathrm{the} \mathrm{determination} \mathrm{of} 19$ consequences out of a total of 22 risks of stage 2 audits show that the audits which were conducted by using the PAF have facilitated the process of risk identification, which signify the first stage of any risk assessment program. However, the degree of risk assessment at the time of audit is considered incomplete because it was not possible to determine the probabilities and severities of these risks at that time.

Additionally, no OFI were determined during stage 1 and stage 2 audits, but they have only been determined during the management review meeting (MRM) that was held subsequent the audits.

As a result, the organizations in order to audit their risk management, they need to: audit each department in combination with its internal customer; involve their auditors in risk assessment; Perform pre-audit in the form of selfauditing; perform focus group by management review meeting.

It is concluded that the role of auditors as risk identifiers was realized by applying this PAF, but their role as risk assessors could not be realized.

\subsection{Auditing of Improvement:}

By virtue of the analysis by themes, this management review meeting (MRM) resulted in determination of some of the opportunities that would lead to the adoption of new practices such as, launching new products, opening new markets, addressing new clients, building partnerships, and using new technology.

Auditing of improvement could not be realized during the time of the audit, but it has been realized by determining the added value after completion the following cycle: 
- $\quad$ performing the audits by use of the PAF.

- $\quad$ analyzing the results of these audits by themes.

- $\quad$ discussing the result of this analysis in the management review meeting.

Evaluating the output of analysis by themes and MRM against the objectives of audits in terms of improvement.

Therefore, in order to determine the improvement deriving from these audits, the results of the data analysis by themes and the output of the MRM were evaluated to determine added value, new, generic and indicatives that were attained.

\section{Evaluation of the Output of Data Analysis and the Contribution of this Research}

6.1 What are the added value, new, generic and indicatives that organizations attain from this research?

To answer this question, the results of the data analysis by themes and the output of the MRM were compared with the most up-to-date relevant literature and this resulted in the determination of the values that are shown below in Table XI.

\begin{tabular}{|c|c|c|}
\hline \multicolumn{3}{|c|}{ Table 11 of 12} \\
\hline $\begin{array}{l}\text { What it has been } \\
\text { accomplished so } \\
\text { far? }\end{array}$ & $\begin{array}{l}\text { To date, what have associated researchers } \\
\text { developed during the last two decades? }\end{array}$ & What is the added value? \\
\hline $\begin{array}{l}\text { 1- Development of } \\
\text { an Audit } \\
\text { Enhancement } \\
\text { Framework }\end{array}$ & $\begin{array}{l}\text { The added value that was gained by Boeing } \\
\text { Aerospace from its integration of the management } \\
\text { tools within the 4P Model to develop a business } \\
\text { excellence framework (BEF) as reported by } \\
\text { Dahlgaard, Chen, Jang, Banegas and Dahlgaard Park, } \\
\text { 2013). }\end{array}$ & $\begin{array}{l}\text { Enhancing the ISO } 9001 \text { quality audit } \\
\text { to help organizations to audit their } \\
\text { performance, risk management and } \\
\text { improvement collectively. Enhancing } \\
\text { the role of auditors to include problem } \\
\text { solver and risk identifier. (Added } \\
\text { value) }\end{array}$ \\
\hline $\begin{array}{l}\text { 2- Using the QMPs } \\
\text { of the ISO } \\
9001: 2015 \text { Standard } \\
\text { as a model for } \\
\text { auditing. }\end{array}$ & $\begin{array}{l}\text { The use of just three QMPs out of a total of seven was } \\
\text { demonstrated by authors like Hoyle (2004), Coleman } \\
\text { (2015) and Smoth (2016). These three principles are; } \\
\text { Engagement of People, Process Approach and } \\
\text { Improvement. }\end{array}$ & $\begin{array}{l}\text { The use of all seven principles } \\
\text { severally or collectively was } \\
\text { demonstrated. (Added value) }\end{array}$ \\
\hline
\end{tabular}




\begin{tabular}{|c|c|c|}
\hline 3-Self-auditing & $\begin{array}{l}\text { There are not many authors who have investigated } \\
\text { this topic. Karapetrovic and Willborn (2002) } \\
\text { proposed a model for conducting individual self- } \\
\text { audits. Also, Canon (1998) states that before audit can } \\
\text { be conducted, standards of performance must be } \\
\text { established and implemented. }\end{array}$ & $\begin{array}{l}\text { Self-auditing was demonstrated by } \\
\text { implementing the proposed PAF and } \\
\text { enhanced by involving the internal } \\
\text { customer of the audited process with } \\
\text { the auditees team. (Added value). }\end{array}$ \\
\hline $\begin{array}{l}\text { 4- Auditor's skills in } \\
\text { qualitative data } \\
\text { analysis is needed. }\end{array}$ & $\begin{array}{l}\text { ISO 9001:2015 focused on the trend analysis. The } \\
\text { management review shall be planned and carried out } \\
\text { taking into consideration ... information on the } \\
\text { performance and effectiveness of the quality } \\
\text { management system, including trends in...NCs, risks } \\
\text { and opportunities..." (Cl. } 9.3 .2 \mathrm{C}) \text {. } \\
\text { Coleman (2013) focused on auditor's skill in RCA. }\end{array}$ & $\begin{array}{l}\text { Further themes with their relationships, } \\
\text { intensities and frequencies have been } \\
\text { determined during the MRM as a result } \\
\text { of applying the Content Analysis by } \\
\text { themes (Generic). }\end{array}$ \\
\hline $\begin{array}{l}\text { 5-The selection of } \\
\text { audit samples should } \\
\text { be based on: } \\
\text { complexity, volume, } \\
\text { risk, past problems } \\
\text { and audit time span. }\end{array}$ & $\begin{array}{l}\text { The rule of Kausek (2008), which is 'Never let the } \\
\text { auditee pick the samples'. He (2016, P. 31) replied to } \\
\text { the new auditor's question, "How many samples } \\
\text { should be drawn and checked? By the answer of: If } \\
\text { time allows, the more the better. He (2016) believed } \\
\text { that randomness is not always effective and it may } \\
\text { mislead the auditor. }\end{array}$ & $\begin{array}{l}\text { Performing self-auditing (stage } 1 \text { audit) } \\
\text { prior to the main audit helped the } \\
\text { auditor of stage } 2 \text { audit to overcome the } \\
\text { audit time limitation by determining } \\
\text { more audit evidence by means of } \\
\text { information provided in advance. } \\
\text { (Indicative). }\end{array}$ \\
\hline $\begin{array}{l}\text { 6- Auditing several } \\
\text { departments in } \\
\text { combination. }\end{array}$ & $\begin{array}{l}\text { Bell and Waters, (2014, P. 211) stated that "the } \\
\text { interviews reveal only how people perceive what } \\
\text { happens, not necessarily what actually happens." }\end{array}$ & $\begin{array}{l}\text { Interviewing many auditees in } \\
\text { combination helped to answer the } \\
\text { question; What actually happened? } \\
\text { (Added value). }\end{array}$ \\
\hline $\begin{array}{l}\text { 7- The internal audit } \\
\text { should not be closed } \\
\text { out until performing } \\
\text { MR. }\end{array}$ & $\begin{array}{l}\text { ISO 9001:2015 and ISO } 19011 \text { emphasized that the } \\
\text { audit is completed and closed out when the audit } \\
\text { planned activities have been carried out. }\end{array}$ & $\begin{array}{l}\text { Determination of further audit data } \\
\text { during the MR was demonstrated. } \\
\text { (Added value). }\end{array}$ \\
\hline
\end{tabular}

As a result of the data evaluation that appeared in Table XI, and in order to determine whether the PAF did provide a practical performance measure guide for internal auditing, further validation for this framework was taken place in the form of workshops. Three workshops were conducted to get the view of further participants who are the five internal auditors in addition to the previous participants (the five auditees). All of these ten participants were called to comment, corroborate, confirm, validate and evaluate the preliminary auditing framework (PAF) based on the evaluation criteria of Platts (1993).

\subsection{Evaluating the Purposed PAF by Determining Its Linkage with the Customer Complaints}

To verify whether the proposed PAF would assist the organizations that experience difficulties with the current ISO 9001 quality audits to achieve their planned objectives with regard to their auditing of conformance, performance, risk management and improvement collectively, it is important to refer to the following interpretations: 
i- $\quad$ the majority of the discovered NCs during Stage 2 audits (23 out of 46) were issued in cases where the requirements related to an intended or specified use were not followed.

ii- the majority of the discovered AFs were systematic and related to the integrity and reliability of the main core of organizational product (pipeline and infrastructures) and also process effectiveness.

iii- $\quad$ the causes of most AFs were easily determined by involving the auditors in problems solving; and by using plurality of problem solving tools, such as the RCA, 5Whys and 5Ms.

iv- $\quad$ The total results of stage 1 and stage 2 audits revealed that they were effective in identification of 34 risks out of a total of $70 \mathrm{AFs}(49 \%)$.

v- The group interview by the management review meeting was effective in identifying and addressing the types of consequences of the risks identified.

vi- $\quad$ Auditing of improvement could not be realized during the time of the audit, but it has been realized during the stage of management review meeting (MRM) by means of the result of data analysis by themes that was presented into this meeting.

vii- $\quad$ By virtue of the analysis by themes, this management review meeting (MRM) resulted in determination of some of the opportunities that would lead to the adoption of new practices.

\subsection{Evaluation of the proposed PAF}

Based on the discussions in these three workshops, and for validating the proposed auditing framework, It is agreed by the participants and the first author of this paper to minimize the risk of effect of the individual characteristic of the auditor (the first author) by shorting and limiting the PAF to the questions and guidelines that have revealed to discovering valid, major, factual, chronic and systematic audit findings in terms of the audit's pillars of conformance, performance, risk management and improvement and that led to the discovery of the added value, indicatives and/or generic that are shown in Table XI. Consequently, the questions that did not lead to any discovery were removed despite the fact that the audit should identify all types of audit findings. The other benefit that associated with this removal is minimizing the risk of stress concentration by the auditor and auditees, because the first version of this framework that consist of 132 questions would not be easy to be followed by other auditors.

Therefore, and as a result of this evaluation which was conducted in accordance with Platts (1993) evaluation criteria, the PAF has been shortened to include 56 questions and 7 guidelines.

\subsection{The Final Version of the Auditing Framework (Table XII)}

The final version of the auditing framework was derived from the first version PAF that was developed from the CAF. This final version is illustrated below in Table XII. 
Table 12 of 12

\section{Part 1: Preamble}

This framework would be subject to change by incorporating different management tools, but it has to be ensured that the selected tools are related to ISO 9001:2015 QMPs and can be applied within the audit phases. However, this auditing framework has to be based on the following elements that compose the CAF:

\begin{tabular}{|c|c|c|c|c|c|c|}
\hline \multirow{3}{*}{$\begin{array}{c}\text { ISO } \\
\text { 9001:2015 } \\
\text { Principle }\end{array}$} & \multirow{3}{*}{$\begin{array}{l}\text { Their relevant } \\
\text { management } \\
\text { tools/techniques }\end{array}$} & \multicolumn{5}{|c|}{ Phases of audit } \\
\hline & & \multicolumn{3}{|c|}{ Planning } & \multicolumn{2}{|c|}{ Execution } \\
\hline & & Scheduling & $\begin{array}{c}\text { Promote } \\
\text { awareness }\end{array}$ & Checklist & $\begin{array}{l}\text { Problem } \\
\text { definition }\end{array}$ & $\begin{array}{l}\text { Problem } \\
\text { solving }\end{array}$ \\
\hline
\end{tabular}

\section{Part 2: Audit Questionnaires Checklist}

QMP Number 1: Customer Focus and QMP Number 7: Relationship Management (5 questions)

\begin{tabular}{|l|l|}
\hline 1 & $\begin{array}{l}\text { Which are the main departments that represent your internal customers? How do you reflect the } \\
\text { requirements/ needs / expectation / preferences of these internal customers in your processes and } \\
\text { organizational structure? }\end{array}$ \\
\hline 2 & $\begin{array}{l}\text { How do you verify that all relevant quality dimensions of product and service industry are identified, } \\
\text { measured and improved? } \\
\text { Verify the consistency between these dimensions and the department's objectives and indicators. }\end{array}$ \\
\hline 3 & $\begin{array}{l}\text { At your department, what factors need more attention and support than others? How this attention is } \\
\text { translated? }\end{array}$ \\
\hline 4 & $\begin{array}{l}\text { Have you translated the internal customer's requirements into clear and complete specification to your } \\
\text { internal suppliers? }\end{array}$ \\
\hline 5 & $\begin{array}{l}\text { Are the requirements of the next process (your internal customer) maintained, controlled, understood } \\
\text { and clearly identified? }\end{array}$ \\
\hline
\end{tabular}

\begin{tabular}{|l|l|}
\hline \multicolumn{2}{|l|}{ QMP Number 2: Leadership and QMP Number 3: Engagement of People (7 questions) } \\
\hline 6 & $\begin{array}{l}\text { What kinds of leadership techniques are used to ensure that you lead your staff effectively when things } \\
\text { get difficult? How? For example, SWOT, PEST, 5Ms, Listening, empowering, valuing and } \\
\text { communication. What are the measurement results? }\end{array}$ \\
\hline 7 & $\begin{array}{l}\text { How do you ensure that your more experienced employees help less experienced employees? Evidence? } \\
\text { What is the procedure? } \\
\text { What kinds of tools are used? e.g. Coaching, motivation, delegation and benchmarking }\end{array}$ \\
\hline
\end{tabular}




\begin{tabular}{|c|c|}
\hline 8 & How do you retain your talented people? Give examples. \\
\hline 9 & How do you improve the personal effectiveness of your staff? Evidence? \\
\hline 10 & $\begin{array}{l}\text { How do you verify that your staffs have a suitable work space, environment, safety, hygiene, security } \\
\text { and working with no or minimum risk? Records of verification? }\end{array}$ \\
\hline 11 & $\begin{array}{l}\text { Are records maintained of the mistakes made by process operators? Investigated? } \\
\text { Have the causes been determined? } \\
\text { What kind of tools used to identify these causes correctly and accurately? } \\
\text { Have the appropriate corrective actions been taken? Are they effective? Evidence? }\end{array}$ \\
\hline \multirow[t]{2}{*}{12} & $\begin{array}{l}\text { Have these mistakes been analyzed? What is the frequency of these mistakes? How you ensure } \\
\text { prevention of their recurrence? What kinds of tools are used? Why? Which is the most effective one? }\end{array}$ \\
\hline & $\begin{array}{l}\text { QMP Number 4: Process Approach, including the Concepts of PDCA and RBT } \\
\text { (17 questions) }\end{array}$ \\
\hline 13 & $\begin{array}{l}\text { What methods are followed to control your process and its sub processes? Evidence of implementation? } \\
\text { Are they effective? How is effectiveness verified? }\end{array}$ \\
\hline 14 & How is your process planned, performed, monitored, measured, analyzed, evaluated and improved? \\
\hline 15 & What are the most important measurements in your process? \\
\hline 16 & $\begin{array}{l}\text { How do you determine the criticality rating of the equipment, material and structures that belong to } \\
\text { your department? }\end{array}$ \\
\hline 17 & $\begin{array}{l}\text { What are the criteria of criticality rating? } \\
\text { Have these criteria been implemented, measured and improved? }\end{array}$ \\
\hline 18 & How do you determine the complexity rating of your process and sub-process \\
\hline 19 & $\begin{array}{l}\text { What are the criteria of complexity rating? } \\
\text { Have these criteria been implemented, measured and improved? }\end{array}$ \\
\hline 20 & Records of measurement and monitoring of samples of critical products \\
\hline 21 & Records of measurement of complicated processes. \\
\hline 22 & $\begin{array}{l}\text { What risks and threats associated to your process and sub-processes? Who determined these risks? How } \\
\text { were these risks determined? }\end{array}$ \\
\hline 23 & Have these risks been prioritized? By which technique? Why? \\
\hline 24 & $\begin{array}{l}\text { Have these risks been assessed? } \\
\text { Has this Risk Assessment covered all types of threats at your departments, e.g. operational, procedural, } \\
\text { financial and political threats. }\end{array}$ \\
\hline 25 & Which tools are used in the risk assessment? Which is the most effective one? Why? \\
\hline 26 & Have the Failure Mode Effect Analysis (FMEA) been determined? For which components? \\
\hline
\end{tabular}




\begin{tabular}{|l|l|}
\hline 27 & $\begin{array}{l}\text { Have the FMEA been issued for all critical components? Like pipeline? What about the other } \\
\text { components? }\end{array}$ \\
\hline 28 & $\begin{array}{l}\text { Have the Risk Management (RM) been determined for all components that their risks are controlled by } \\
\text { FMEA? }\end{array}$ \\
\hline 29 & $\begin{array}{l}\text { Have you planned to use any one of the strategy tools, like SWOT, PEST and Prioritization Strategy to } \\
\text { help you in the determination of ignored risks? Why / why not? }\end{array}$ \\
\hline
\end{tabular}

\section{QMP Number 5: Improvement, including the Concepts of PDCA and RBT}

(21 questions)

\begin{tabular}{|c|c|}
\hline 30 & What advantages does the Department have? \\
\hline 31 & What unique or lowest-cost resources can they draw upon that others can't? \\
\hline 32 & What could you improve? \\
\hline 33 & What should you avoid? \\
\hline 34 & What good opportunities can your department spot? \\
\hline 35 & What obstacles does your department face? \\
\hline 36 & Have you identified and listed your problems periodically? \\
\hline 37 & Have you identified the root cause of every problem identified? \\
\hline 38 & $\begin{array}{l}\text { What kind of techniques have you used to define these problems correctly and accurately? For example, } \\
4 \mathrm{~W} / 2 \mathrm{H} / 1 \mathrm{C} \text {. }\end{array}$ \\
\hline 39 & $\begin{array}{l}\text { What kind of techniques have you used to determine the root cause of each problem? For example, } \\
\text { RCA, } 5 \text { Whys, and 5Ms. }\end{array}$ \\
\hline 40 & $\begin{array}{l}\text { Have you determined the consequences of each problem and risk? What kinds of risk assessment } \\
\text { techniques are used? E.g. FMEA. }\end{array}$ \\
\hline 41 & $\begin{array}{l}\text { Have you grouped your problems and risks with other problems together by their root causes, } \\
\text { consequences and cost of their correction? }\end{array}$ \\
\hline 42 & $\begin{array}{l}\text { Based on their consequences, cost and root causes, have you identified the highest and lowest priority } \\
\text { by score? }\end{array}$ \\
\hline 43 & $\begin{array}{l}\text { Have the root causes of each one of the non conformities and risks been identified and followed up? } \\
\text { How? By who? }\end{array}$ \\
\hline 44 & How the causes are grouped? Manpower, machine, material, technology, physical, measure, system? \\
\hline 45 & $\begin{array}{l}\text { How the causes are analyzed? } \\
\text { Which tools are used in this analysis? }\end{array}$ \\
\hline 46 & $\begin{array}{l}\text { Has the problem solving tool been applied to determine the root cause of each non conformity? How? } \\
\text { Which tools? 5Ms, RCA and } 5 \text { whys. }\end{array}$ \\
\hline 47 & Has the effective implementation of these tools been followed up? How? By who? \\
\hline
\end{tabular}




\begin{tabular}{|c|c|}
\hline 48 & $\begin{array}{l}\text { What kinds of data analysis conducted? } \\
\text { Quantitative and/or qualitative? Why? } \\
\text { If qualitative, what kind of technique applied? Why? i.e. analysis by themes / Analysis from the } \\
\text { perspective of failure prediction and prevention. }\end{array}$ \\
\hline 49 & How did you ensure of the validity, reliability and/or credibility of that analysis? \\
\hline 50 & $\begin{array}{l}\text { Have the results of that analysis been evaluated against agreed objectives and indicators? } \\
\text { QMP Number 6: Evidence Based Decision Making } \\
\text { (6 questions) }\end{array}$ \\
\hline 51 & $\begin{array}{l}\text { Have the above data analysis been considered by you and your top management, when you intend to } \\
\text { take decisions? How? Evidence? }\end{array}$ \\
\hline 52 & Have you been consulted or involved in making of such decisions? How? \\
\hline 53 & $\begin{array}{l}\text { What kinds of Decision Making Tools are used? For example, PDCA and prioritization. } \\
\text { Are they effective? Give evidence. }\end{array}$ \\
\hline 54 & $\begin{array}{l}\text { For making decisions, have you applied the appropriate Model? Like: Observe-Orient-Decide-Act Loop } \\
\text { / Plan-Do-Check-Act Model? /How? Records of application? }\end{array}$ \\
\hline 55 & $\begin{array}{l}\text { Before making the decision, have you: } \\
\text { Identified and analyzed the problem by use of one of the problem definition tool and problem solving } \\
\text { tools? } \\
\text { Developed and tested a potential solution by use of some techniques like Impact Analysis? }\end{array}$ \\
\hline 56 & After making decisions, have you implemented the improved solution fully? How? \\
\hline \multicolumn{2}{|c|}{ Part 3: Guidelines } \\
\hline \multicolumn{2}{|r|}{$\begin{array}{l}\text { 1- List of the documents that need to be reviewed by auditors and auditees prior to audit. (They usually includes: } \\
\text { policy and its objectives; manuals; plans; procedures; work instructions; standards, guidelines, specifications, } \\
\text { drawings, forms; reports; previous internal audit reports, risk assessment reports, management review reports, the } \\
\text { internal customer feedback report). }\end{array}$} \\
\hline \multicolumn{2}{|r|}{ 2- Listing the most important parts of that documents that need attention as an appendix. } \\
\hline \multicolumn{2}{|r|}{$\begin{array}{l}\text { 3- List of the evidence which demonstrate that none of the above documents and reports contain untruthful } \\
\text { information. }\end{array}$} \\
\hline \multicolumn{2}{|r|}{$\begin{array}{l}\text { 4- List of the evidence which demonstrate that awareness of the auditee to the relevant documents, record, and } \\
\text { relevant management tools is adequate. }\end{array}$} \\
\hline \multicolumn{2}{|c|}{ 5- Comment on the capability of the auditee to conduct an effective self-audit. } \\
\hline \multicolumn{2}{|c|}{ 6- Comment on audit data analysis report. } \\
\hline & nt on the management review \\
\hline
\end{tabular}




\section{Guidance of the suggested auditing framework}

It can be noticed from this framework that the QMP number 4 (Process Approach) and QMP number 5 (Improvement) of the ISO 9001:2015 Standard are represented by 38 questions out of a total of 56. In other words, the QMP number 4 and QMP number 5 represent $67 \%$ of the content of this framework. Therefore, these authors have to answer the predictable question that the practitioners and academics could say it in that way; why do these authors divided the seven QMPs amongst the framework unequally? To answer this question, it is important to refer to the CAF and then to consider the following points:

- $\quad$ The concepts of PDCA and RBT are embedded within these two principles (QMPs number 4 and 5) that form the highest proportion of the framework.

- The other QMPs, which are the principles number 1, 2, 3, 6 and 7 are concentrated and embedded within the other phases of audits, which include the planning, scheduling, determining the auditee team, problem definition, problem solving and data analysis.

Bearing in mind that this final version of the Auditing Framework should not be categorized as an Auditing Questionnaires Checklist, because the audit is dynamic and should not be controlled by static/fixed checklist. However, This PAF can be categorized as an Enhancement Auditing Questionnaires Checklist, because it enhances and enriches any ISO 9001 Quality Auditing Questionnaires Checklist.

This final version of the auditing framework (Table XII) would also be subject to change to include different guides that could also enhance the audit's effectiveness in different ways, which may include the following concerns:

- This auditing framework should also be used to promote the auditee's awareness of the audit criteria to enable them to perform an efficient self-auditing prior to being subjected to the main audit. Therefore, this framework would be subject to change to incorporate different audit criteria and different guiding material that further auditees may need to be familiar with.

- Only 12 tool were integrated within this framework, but there is a significant number of management tools available which meet the selection criteria (section 2.3). Therefore, it is important to coach the auditors and self-auditors on how, when and which tools should be used in the audit's phases of planning, execution, problem definition, risk identifications and problem solving.

\section{$7 \quad$ Conclusion}

This research is focused on how to utilize ISO 9001 in a way that helps the organizations to audit the conformance, performance, risk management and improvement in combination. In this way, the auditing approach will be changed from ISO 9001 elements to ISO 9001 principles by integrating the most appropriate tools that are related to these principles severally and collectively. To attain this objective, an auditing framework was developed by the authors of this study.

This study revealed that the seven ISO 9001:2015 principles can be integrated within the proposed auditing framework through their related management tools. It is also demonstrated that these selected tools are consistent with some of 
the audit limitations that have been previously reported in the literature and are connected with all of the customer complaints that have been identified in the research rationale.

By applying this framework, the role of auditor was enhanced to include; problem solving, risk identification and data analysis/evaluation. However, the role auditor as risk assessor could not be realized. On the other hand, the role of the auditee to be self-auditor was also realized by applying this framework.

Applying this framework indicated that in order to help organizations to audit their conformance, performance, risk management and improvement in combination, they need to; 1) change their audit approach from ISO 9001 elements to ISO 9001 QMPs, 2) integrate the management tools that are related to ISO 9001 QMPs within the phases of audit, 3) perform pre-audits in the form of self-auditing, 4) induce and encourage their auditors to learn all management tools to determine the ideal tools for particular situation, and to attain the skills needed for assertion and sampling, 5) audit each department in combination with its internal customer, 6) involve their auditors in problem solving an risk assessment 7) Perform management review prior to closing the audit, 8) develop qualitative metrics to measure the performance of their audits, and 9) analyzing the results of audits with their causes by using one of the appropriate qualitative methods, such as analysis by themes.

The output of this research indicated that the change of auditing approach from ISO 9001:2015 elements to ISO 9001.2015 principles and the use of the management tools by the auditors are needed.

\section{References:}

1- $\quad$ Abuazza, O., Elaish, R. and Nawa, K. (2007). Evaluation of Cathodic Protection Criteria in Pre-Stressed Concrete Cylinder Pipe of the Great Man-made River Project, Libya. Paper presented at Corrosion/2007 Conference: Committee Meeting of NACE International Task Group-019 - Nashville, Tennessee, USA, 1014 March.

2- Anderson, V. (2013), The Implication of Managerial Coaching for Leadership Theory; Human Resource Development International, 16 (2013), University of Portsmouth, UK February 2013.

3- $\quad$ Barlow, T. (2013). Auditing by RBT Concept: How to apply risk to your quality management system. Paper presented at $A S Q 2^{2 \text { nd }}$ Audit Division Conference. Tucson, AZ, USA.

4- $\quad$ Bell, J. \& Waters, S. (2014). Doing your research project: a guide for first-time researchers $\left(6^{\text {th }} \mathrm{ed}\right)$. Maidenhead: Open University Press.

5- $\quad$ Broadleaf (2014). Relationship between internal audit and risk management. Published under Governance assurance and oversight. Retrieved from:

http://broadleaf.com.au/resource-material/relationship-between-internal-audit-and-riskmanagement/3/22/17.

6- Canon, M. (1998). "Under the Microscope: Self-Managed Audits are an Excellent Tool for Evaluation and Managing EH\&S Programs”. Occupational Health and Safety Journal. 67(1), 18-60. 
7- Coleman, L. B. (2013). How Delightful is your Audit Program? Paper presented at ASQ 22 $2^{\text {nd }}$ Audit Division Conference on October 2013. Tucson, AZ, USA.

8- Coleman, L. B. (2015). Advanced Quality Auditing: An Auditor's review of Risk Management, Lean Improvement and Data Analysis (Quality Press, 2015).

9- Dahlgaard, J., Chen, C., Jang, J., Banegas, L. \& Dahlgaard Park, S. (2013). Business Excellence Models: Limitations, Reflections and Further Development. Total Quality Management \& Business Excellence. 24(5-6), 519-538.

10- Deysher, B. (2015). A Risk Based Thinking Model for ISO 9001:2015. ASQ Conference (January 2015).

11- EFQM (2016). The new ISO Standards on Management Systems \& The EFQM Excellence Model. EFQM Leading Excellence Leaflet (2016).

12- $\quad$ Freeman, R. \& Drown, J. (2015), Making Business Sense of Risk. ASQ Standards Connection (August 2015).

13- He, B. (2016). Auditing: Elephant in the Room: A centuries-old tale offers lessons for effective audits. ASQ Quality Progress (issue 29), October.

14- Hoyle, D. \& Thompson, J. (2004). A Guide to Business Process Management (1 ${ }^{\text {st }}$ ed.). Gloucestershire UK: Transition Support Ltd.

15- IPPF, (2010), Measuring Internal audit effectiveness and efficiency, Practice guide, Institute of Internal Auditors IIA. Retrieved from www.theiia.org/guidance.

16- ISO 9001:2015, International Organization of Standardization (ISO), Quality Management System - Requirement.

17- $\quad$ ISO 19011:2011, International Organization of Standardization (ISO), Guidelines for auditing management systems.

18- ISO Publication (2015), Quality Management Principles $\left(2^{\text {nd }} \quad\right.$ ed. $)$ retrieved from: www.iso.org/publication/PUB100080.html.

19- Karapetrovic, S. \& Willborn, W. (2000). Quality assurance and effectiveness of audit systems, International Journal of Quality and Reliability Management, 17(6), 679-703.

20- Kausek, J., (2008a). 10 Auditing Rules. ASQ Quality Progress (July).

21- Kimotho, T. N. (2014). Factors Affecting Internal Audit Independence: A Case Study of Technical University of Mombasa. European Journal of Business and Management, 6(6), 145-154.

22- Malsbury, J. (1999). Audits that make a difference. Proceedings of the ASQ's 53rd Annual Quality Congress. NJ. USA.

23- PECB, (2016). Official training on Advanced Auditing Techniques. PECB, Montreal, Canada.

24- Platts, K.W. (1993). A process approach to researching manufacturing. International Journal of Operations \& Production Management. 13(8), 4-17.

25- PwC's. (2014), Metrics by design. A practical approach to measuring internal audit performance. State of Internal Audit Profession. Internal Audit Leaders in Canada and US. Retrieved from: www.pwc.com/ca/internalaudit. 
26- Ramly, E. F., Ramly, E. S. \& Yusof, S. M. (2008). Effectiveness of Quality Management System Audit to Improve Quality Performance - A Conceptual Framework. The Fifth International Conference on Quality and Reliability. www.researchgate.net/publication/267400023.

27- Russell, J. P. (2006). Process Auditing and Techniques. ASQ Quality Progress (June).

28- Russell, J. P. (Ed) (2013). ASQ Auditing Handbook, Principles, Implementation and Use (4 ${ }^{\text {th }}$ ed.). Milwaukee, Wisconsin: ASQ Quality Press, ISBN: 978-0-87389-847-8.

29- Sandle, T. (2016). Risk based Approach to Internal Quality Auditing. IVT Institute of Validation Technology Journal (25 February 2016).

30- Smoth, S. (2016), Auditing Using Lean and Six Sigma Tools. The Audit Report: The Newsletter of the ASQ Audit Division (Issue 21), May 2016.

31- Swanson, D. (2006). IT Audit Checklist: Risk Management. IT Compliance Institute (ITCi) Practical guidance on how to prepare for successful audits.

32- The Great Man-made River Project Authority, GMRA. (2014). Management Review Report (December). Unpublished internal document. 